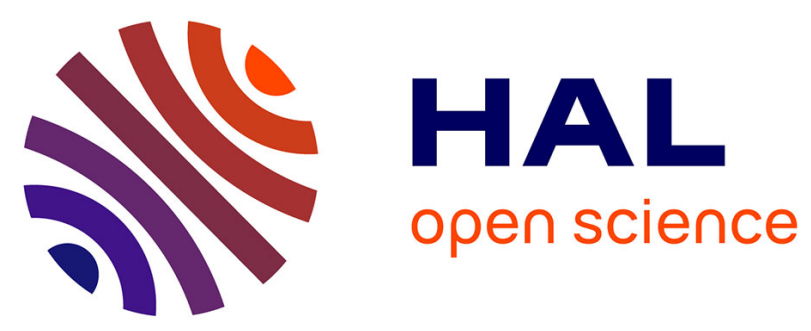

\title{
Isolation and genotyping of viable Toxoplasma gondii from sheep and goats in Ethiopia destined for human consumption
}

\author{
Endrias Zewdu Gebremedhin, Mukarim Abdurahaman, Tesfaye Sisay \\ Tessema, Getachew Tilahun, Eric Cox, Bruno Goddeeris, Pierre Dorny, \\ Stephane de Craeye, Marie-Laure Dardé, Daniel Ajzenberg
}

\section{To cite this version:}

Endrias Zewdu Gebremedhin, Mukarim Abdurahaman, Tesfaye Sisay Tessema, Getachew Tilahun, Eric Cox, et al.. Isolation and genotyping of viable Toxoplasma gondii from sheep and goats in Ethiopia destined for human consumption. Parasites \& Vectors, 2014, 7, pp.425. 10.1126/science.1078035 . inserm-01091618

\section{HAL Id: inserm-01091618 https://www.hal.inserm.fr/inserm-01091618}

Submitted on 5 Dec 2014

HAL is a multi-disciplinary open access archive for the deposit and dissemination of scientific research documents, whether they are published or not. The documents may come from teaching and research institutions in France or abroad, or from public or private research centers.
L'archive ouverte pluridisciplinaire HAL, est destinée au dépôt et à la diffusion de documents scientifiques de niveau recherche, publiés ou non, émanant des établissements d'enseignement et de recherche français ou étrangers, des laboratoires publics ou privés. 


\title{
Isolation and genotyping of viable Toxoplasma gondii from sheep and goats in Ethiopia destined for human consumption
}

\author{
Endrias Zewdu Gebremedhin ${ }^{*}$, Mukarim Abdurahaman², Tesfaye Sisay Tessema ${ }^{3}$, Getachew Tilahun ${ }^{4}$, Eric Cox ${ }^{5}$ \\ Bruno Goddeeris ${ }^{5,6}$, Pierre Dorny ${ }^{5,7}$, Stephane De Craeye ${ }^{8}$, Marie-Laure Dardé ${ }^{9,10}$ and Daniel Ajzenberg ${ }^{9,10}$
}

\begin{abstract}
Background: Toxoplasma gondii is an obligate intracellular protozoan parasite that infects humans and a broad spectrum of warm-blooded vertebrates. The present study was undertaken with the objectives of isolation and determining the genotypes of T. gondii strains from sheep and goats slaughtered in East and West Shewa Zones of Oromia Regional State, Central Ethiopia.

Methods: Hearts of 47 sheep and 44 goats that were seropositive in the Direct Agglutination Test (DAT) were bioassayed in mice. A multiplex PCR assay with 15 microsatellite markers was employed for genotyping of $T$. gondii isolates from sheep and goats.

Results: Viable T. gondii were isolated from 47 (51.65\%) animals, 27 sheep and 20 goats. Most isolates caused sub-clinical infections in mice, however, 2 sheep and 1 goat isolates were mouse-virulent, killing mice between 19-27 days post-inoculation. The success of $T$. gondii isolation in mice increased significantly $(P=0.0001)$ with higher DAT antibody titers in sheep and goats. Genotyping revealed that 29 (87.88\%) of the 33 isolates were Type II, 3 (9.09\%) were Type III and 1 (3.03\%) was atypical. Three strains (one type II, one type III, and the atypical genotype) were virulent for mice.

Conclusions: T. gondii tissue cysts in sheep and goats slaughtered for human consumption are widespread. This is the first report on isolation and genotyping of T. gondii from sheep and goats of Ethiopia.
\end{abstract}

Keywords: Toxoplasma gondii, Bioassay, DAT, Ethiopia, Sheep, Goat, Genotyping, Microsatellite, Atypical, Virulent

\section{Background}

Toxoplasma gondii is an obligate intracellular protozoan parasite that infects humans and a broad spectrum of warm-blooded vertebrates [1]. In humans, accidental ingestion of oocysts shed in feline faeces and consumption of raw or undercooked meat containing $T$. gondii tissue cysts are the major routes of transmission. In addition, if infection occurs during pregnancy, the parasite can cross the placenta and infect the fetus (congenital transmission) leading to abortion or congenital abnormalities [2,3].

\footnotetext{
* Correspondence: endrias.zewdu@gmail.com

${ }^{1}$ Faculty of Agriculture and Veterinary Sciences, Department of Veterinary Laboratory Technology, Ambo University, P. O. Box 19, Ambo, Ethiopia Full list of author information is available at the end of the article
}

Previously, it was described that $T$. gondii has a clonal population structure consisting of three genetic lineages i.e., Type I, Type II and Type III [4]. However, recent studies with multilocus markers indicate greater genetic diversity than initially thought among isolates of $T$. gondii worldwide $[5,6]$. Toxoplasma gondii presents a complex population structure with a mix of clonal and sexual propagation [5]. Epidemiological and population studies with multilocus PCR-RFLP or microsatellite markers have shown that $T$. gondii isolates from South America are highly diverse and distinct from those from North America and Europe, where Type II is predominant [5-13].

Few data are available on toxoplasmosis in both public health and veterinary sectors in Ethiopia [14]. Genotyping of $T$. gondii isolates using RFLP-PCR from 27 feral cats from Addis Ababa indicated limited genetic diversity [15]. 
The microsatellite (MS) genotyping technique is an easy-to-use and rapid genotyping method, which aims to ensure both levels (lineage and fingerprinting) of genetic discrimination of $T$. gondii isolates in a single multiplex PCR assay, using 15 MS markers located on 11 different chromosomes of $T$. gondii $[9,16]$. The association of the 15 MS markers with different mutability patterns enables two different levels of genetic resolution for differentiating $T$. gondii strains at the typing level (types I, II, and III versus atypical strains) and at the fingerprinting level (closely related isolates within a clonal lineage). Microsatellite genotyping has a similar sensitivity with that of intron sequencing and a better resolution level to distinguish genetically closely related strains compared to PCR-RFLP [16].

The aim of the present study was to isolate and genotype $T$. gondii strains from sheep and goat heart tissues in Central Ethiopia.

\section{Methods}

\section{Naturally exposed sheep and goats}

Most of the sheep and goats studied originated from Adea, Fentale (East Shewa Zone) and Ambo (West Shewa Zone) districts. The location, altitude, climate, breed and production system of sheep and goats of these districts have been described previously [17].

Sheep and goats of the study areas slaughtered for human consumption at an export abattoir in Debre Zeit town were traced and identified using information supplied by the attendant and the abattoir manager. Production system, breed and purpose of keeping small ruminants (for meat and milk) are as described previously $[17,18]$. In this study, sheep and goats aged over six months were sampled. The majority of the animals were males; few females were sampled because they are normally kept for breeding purpose and majority of those arriving at the abattoir are culls and infertile animals.

\section{Identification of seropositive animals}

As part of an epidemiological study of $T$. gondii in sheep and goats of the East and West Shewa Zones of Central Ethiopia, 628 sera were tested using the direct agglutination test (DAT) (Toxo screen DA, Biomerieux ${ }^{\oplus}$, France). The present study was undertaken from September, 2011 to June, 2013 using hearts of 91 DAT seropositive animals (47 sheep and 44 goats) and 14 seronegative animals (10 sheep and 4 goats) from previous seroepidemiological study [18].

\section{Bioassay of sheep and goats hearts for $T$. gondii}

Approximately $50 \mathrm{~g}$ of heart tissue was prepared as described previously [1]. Briefly, each sample was cut in small pieces of approximately $1 \mathrm{~cm}^{3}$, homogenized in a blender for $30 \mathrm{sec}$, followed by suspension in $125 \mathrm{ml}$ of saline solution $(0.14 \mathrm{M} \mathrm{NaCl})$ for another $30 \mathrm{sec}$. After homogenization, $250 \mathrm{ml}$ of a pepsin solution (i.e. porcine stomach pepsin of 1:0000 biological activity $5.2 \mathrm{~g}, \mathrm{NaCl}$ $10.0 \mathrm{~g}, \mathrm{HCl} 14 \mathrm{ml}$, and distilled water to make 1,000 ml, pH 1.10-1.20) (Merck KG.A, Darmstadt, Germany) was added. After an incubation of $1 \mathrm{~h}$ at $37^{\circ} \mathrm{C}$, the homogenate was filtered through two layers of gauze and centrifuged at $1200 \times g$ for $10 \mathrm{~min}$. The supernatant was discarded and the pellet was resuspended in 15 to $20 \mathrm{ml}$ of $1.2 \%$ sodium bicarbonate solution $(\mathrm{pH}=8.3)$ and recentrifuged at $1200 \times g$ for $10 \mathrm{~min}$. The supernatant was discarded and the sediment was re-suspended in 5 to $10 \mathrm{ml}$ of antibiotic saline solution $(1000 \mathrm{U} / \mathrm{ml}$ penicillin and $100 \mu \mathrm{g}$ streptomycin/ml in saline solution). One milliliter of this suspension was inoculated intraperitoneally (i.p.) in five mice per sample [1]. Bioassays were performed within 1 to 3 days after the slaughter of the animals. The mice used were $T$. gondii seronegative female Swiss Albino mice, obtained from the animal facility of the National Veterinary Institute, Debre Zeit, Ethiopia. Non-infected mice $(n=5)$ were kept separately as negative controls. The mice were given commercial pelleted feed and municipal chlorinated water ad libitum.

The inoculated mice were observed daily for the presence of clinical signs until day 60 post inoculation. The number of survivors, the presence of clinical signs, the weight and the eventual mortality (day of death) were recorded. A T. gondii isolate was considered virulent if mortality of mice was observed within four weeks of infection [19].

The mice were bled on day 60 post-inoculation and their sera tested for T.gondii-antibodies by the direct agglutination test (DAT) following the procedure described by manufacturer of the kit (Toxo screen DA, biomerieux ${ }^{\oplus}$, France) as described previously. Sera were assayed at dilutions of 1/40 and 1/4000; a titer of 1: 40 was considered indicative of $T$. gondii exposure.

Two months after intraperitoneal (i.p) inoculation, the brain from surviving mice was removed after euthanasia with di-ethyl ether. Each brain was homogenized in $1 \mathrm{ml}$ PBS ( $\mathrm{pH} 7.2$ ) using a mortar and pestle. Following microscopic examination and counting of cysts, the homogenates were stored in $1.5 \mathrm{ml}$ Eppendorf tubes and frozen at $-20^{\circ} \mathrm{C}$ until DNA extraction was done. The number of cysts in three aliquots of each $10 \mu$ l was counted under a light microscope with a 100X magnification. The total number of cysts in the brain of each mouse was determined by converting the sum of cysts in $30 \mu \mathrm{l}$ to the whole volume of the brain homogenates $[1,20,21]$. A bioassay was considered positive if $T$. gondii cysts were detected in any of the five inoculated mice. 


\section{DNA extraction}

DNA was extracted from mice brain as described previously by Su and Dubey [22] using the QIAamp Tissue kit (Qiagen). Briefly, 75-100 $\mu$ l of homogenized brain (approximately $25 \mathrm{mg}$ brain tissue), $180 \mu \mathrm{l}$ of lysis buffer of the kit (ATL) and $20 \mu \mathrm{l}$ of proteinase $\mathrm{K}$ were added and incubated at $56^{\circ} \mathrm{C}$ until the tissue was completely lysed (60 to $90 \mathrm{~min}$ ). The lysate was then mixed with $200 \mu \mathrm{l} \mathrm{AL}$ buffer and incubated for another $10 \mathrm{~min}$ at $70^{\circ} \mathrm{C}$. DNA was precipitated by addition of $200 \mu$ ethanol (96-100\%). Then, the mixture was carefully applied to the QIAamp Mini spin column and centrifuged at $6000 \times \mathrm{g}$ for $1 \mathrm{~min}$. The columns were then washed by centrifugation using buffers AW1 and AW2, according to the manufacturer's instruction. Finally, the DNA was eluted from the column using $50 \mu \mathrm{l}$ of the elution buffer of the kit (AE) and stored at $-20^{\circ} \mathrm{C}$ until used for genotyping.

\section{Multiplex-PCR Microsatellite genotyping}

$T$. gondii strains were genotyped using 15 microsatellite markers distributed on 11 of 14 chromosomes in a single multiplex PCR-assay, as described previously [16] (see Additional file 1 for details). Briefly, for each primer pair, the forward primer was 5'-end labeled with fluorescein to allow sizing of PCR products that were separated by electrophoresis in an automatic sequencer. PCR was carried out in a $25 \mu \mathrm{L}$ reaction mixture consisting of $12.5 \mu \mathrm{l}$ multiplex PCR Master Mix (Qiagen, France), $7.5 \mu \mathrm{l}$ primer mix for $15 \mathrm{MS}$, and $5 \mu \mathrm{l}$ of DNA template. Cycling conditions were $15 \mathrm{~min}$ at $95^{\circ} \mathrm{C} ; 30 \mathrm{~s}$ at $94^{\circ} \mathrm{C}$, $3 \mathrm{~min}$ at $61^{\circ} \mathrm{C}$, and $30 \mathrm{~s}$ at $72^{\circ} \mathrm{C}(35$ cycles); and the last extension step was $30 \mathrm{~min}$ at $60^{\circ} \mathrm{C}$. PCR products were diluted $1 / 10$ in deionized formamide. One $\mu \mathrm{l}$ of each diluted PCR product was further diluted $1 / 25$ in $23.5 \mu \mathrm{l}$ of deionized formamide and $0.5 \mu \mathrm{l}$ of a dye-labeled size standard (ROX 500; Applied Biosystems). This mixture was denatured at $100^{\circ} \mathrm{C}$ for $5 \mathrm{~min}$ and then electrophoresed using an automatic sequencer (ABI PRISM 3130xl; Applied Biosystems). The sizes of the alleles in base pairs were estimated using GeneMapper analysis software (version 4.0; Applied Biosystems).

\section{Data analysis}

Data generated were recorded and coded using Microsoft Excel and analyzed using STATA version 11.0 for Windows (Stata Corp. College Station, TX, USA). Descriptive statistics such as, percentage, mean, variance, etc. were used to summarize the data. The rate of cyst isolation in mice was compared with the DAT end titer of sheep and goats using the Chi-squared test. The Mann-Whitney $U$ test was used to assess the relationship between parasite isolation in mice and $T$. gondii antibody end titer of sheep and goats, i.e., the median sheep and goats antibody titers related to isolation and no isolation. Fisher's Exact test was used to compare associations between $T$. gondii genotypes and species (sheep, goat), origin (West Shewa, East Shewa), severity (none, moderate, high), number of cysts $(\leq 200,201-500, \geq 501)$ and DAT titer $(\leq 540,1620$ $6000, \geq 18000)$ of sheep and goats.

To quantify the extent of genetic distance among T. gondii isolates from sheep and goats of Ethiopia, and evaluate their position towards reference strains from different continents, Neighbor-joining trees were reconstructed from the genetic distances among individual isolates using Populations 1.2.30 (1999, Olivier Langella, CNRS UPR9034, http://bioinformatics.org/ tryphon/populations/) and the Cavalli-Sforza and Edwards [23] (1967) chord-distance estimator. Unrooted trees were obtained with MEGA 6.06 software. The 95\% confidence interval and a significance level of $\alpha=0.05$ were used.

\section{Ethical issues}

This research project was approved by the animal ethical committee of the College of Veterinary Medicine and Agriculture, Addis Ababa University. All efforts were made to minimize animal suffering during the course of the study.

\section{Results}

\section{Isolation of $T$. gondii}

Viable $T$. gondii strains were isolated from 27 (57.45\%) sheep and $20(45.45 \%)$ goats. The sheep isolates were designated as TgSpEt 1 to 27 and the goat isolates were designated as TgGtEt 1 to 20 (see Additional file 2: Table S1 and Table S2). In general, isolation rate increased with titer of sheep and goats $(P=0.0001)$.

Additionally, viable T. gondii was isolated from 4 of 14 seronegative hearts (from 2 of 10 sheep and 2 of 4 goat samples. Each positive sample gave cyst positive result on one of the five mice). None of these cyst positive mice were DAT positive.

\section{Virulence}

Two sheep isolates were virulent for mice. Isolate TgSpEt21 killed one mouse on 19 days post inoculation (dpi) and isolate TgSpEt19 killed 4 mice between 23-24 dpi. Additionally, one isolate from goat \# 384 (designated as $\mathrm{TgGtEt17)}$ from East Shewa was mouse virulent as it killed one mouse on 27 dpi. Moreover, one sheep isolate (TgSpEt4) and two goat isolates (TgGtEt2 and TgGtEt11) each killed one mouse on day 44, 48 and 47, respectively (see Additional file 2: Table S1 and Table S2). One mouse inoculated with the sample of sheep \# 539 was severely ill between 47-60 dpi, with signs of inappetance, dullness, weight loss, rough hair coat, paralysis, arched back and tachychardia. 


\section{Genotyping}

In total, genotyping data with $15 \mathrm{MS}$ markers were obtained from $T$. gondii isolates of 33 small ruminants of Central Ethiopia (18 sheep and 15 goats) and were compared to those obtained from 14 reference strains collected in America, Africa, Asia, and Europe (Table 1). The Neighbor-joining analysis of these 47 strains is displayed as an unrooted tree in the Figure 1. Out of the 33 strains from Ethiopia, 32 (97\%) were clustered in only two groups: type II and type III (Figure 1). Type II was the most dominant being observed in $29(87.87 \%)$ of the isolates followed by Type III (3/33, 9.09\%). All isolates from West Shewa Zone were Type II. The allelic combination of the isolate TgSpEt19 was atypical and characterized by several unique alleles absent from the other reference strains (Table 1 and Figure 1). This isolate was found on a separate long branch in the Neighbor-joining tree and was clearly divergent from the type I, II, and III strains and did not group with the reference African strains (Figure 1).

The three type III isolates were recovered from two goats and one sheep of East Shewa Zone. The atypical genotype was identified from a sheep of East Shewa Zone (Adea district). Only Type II genotypes were detected from West Shewa. Out of the three Type III isolates, one from goat \# 384 killed one mouse on day 27 and another one from sheep \# 539 made mice seriously ill from day 47-60 with debilitation and weight loss. The other Type III isolate was asymptomatic in mice. One Type II strain from East Shewa from sheep \# 474 designated asTgSpEt21 was virulent for mouse.

Significant difference between DAT titer of sheep and goats in Ethiopia and genotypes $(P=0.027)$ as well as severity of disease in $T$. gondii infected mice and genotypes $(P=0.003)$ were detected with the Fisher's exact test.

\section{Discussion \\ Bioassay}

The ingestion of undercooked mutton was identified as a risk for acquiring toxoplasmosis in pregnant women in Europe [24]. Considering the increasing trend and habit of eating raw or undercooked meat and offal from small ruminants in Ethiopia, the high rate of isolation of viable tissue cysts is of great public health significance. It is a reflection of the high degree of contamination of the environment by oocysts of cats and the outdoor management system of animals [1].

In the present study, viable $T$. gondii parasites were also isolated from 2 of 10 and 2 of 4 seronegative goats and sheep, respectively. The result might be related to the 1:40 cut-off used; viable $T$. gondii has been isolated from sheep and pigs in France with a low DAT titer $(<1: 16)$.

It appears that some of the inoculated mice in the present study failed to seroconvert even after developing brain cysts (Additional file 2: Table S1 and Table S2). It was also felt that the threshold DAT titer indicative of T. gondii infection in mice might be lower than 1:40. Isolation of viable $T$. gondii from DAT and dye test seronegative mice has been reported earlier $[25,26]$. Some mice don't seroconvert even at 8-10 weeks [27].

The present study indicates that 93.6\% (44/47) of T. gondii strains circulating in the study area are nonvirulent for mice. Two of the $27 \mathrm{~T}$. gondii isolates from sheep and 1 of the 20 isolates from goats were virulent, since they killed mice between 19-27 dpi [19]. This is lower compared to a report from Brazil where, 9 of the 16 T. gondii isolates from sheep [28] and 10 of the 12 T. gondii isolates from goats [29] were mouse-virulent. The present mouse virulence detected was largely in agreement with $T$. gondii isolates from sheep in Europe and the United States where none of the 8 isolates from 30 seropositive adult ewes from France [30], and 52 of 53 isolates from lambs from the United States [31] were non-virulent for mice. Seropositive mice which died during the course of follow-up might be linked to the larger dose of bradyzoites received during i.p injection or to the strain of the parasite. Previous studies showed that the virulence of T. gondii in mice is related to the dose, route, stage of the parasite, genotype of the parasite, and strain of mice [32,33].

\section{Genotyping}

Most of the $T$. gondii isolates in the present study belonged to the type II clonal lineage (87.88\%). The Type II clonal lineage is the most common lineage in Europe and North America; the Type III clonal lineage is found occasionally worldwide $[5,7,15]$. The dominance of Type II might be due to its fitness and enhanced ability to outcompete other genotypes (reviewed in RobertGangneux and Dardé, [3] as well as by its ability to form high numbers of cysts $[4,34]$. The Type II genetic lineage has been shown to be the dominant lineage in opportunistic infections in immunocompromised people and in congenital toxoplasmosis in Europe [8,35], and was found in $73 \%$ of cases of ocular disease in France [36]. In contrast, the absence of Type II and overabundance of atypical genotypes are characteristic of $T$. gondii strains from continental Brazil [33].

All isolates from West Shewa were identified as Type II while that of East Shewa additionally contained Type III and atypical lineages. The higher genetic diversity of T. gondii detected in East Shewa could be ascribed to diverse agro-ecologies in this area (altitude ranging from 953 to 3400 masl). Ethiopia served as a historical entry point of many livestock populations from Asia, thousands years ago [37]. The dominance of clonal lineage (Type II) in the present study is in accordance with the long history of breeding and domestication of 
Table 1 Genotyping results of T. gondii DNA with 15 microsatellite markers from 33 isolates collected in sheep and goats of Central Ethiopia and from 14 reference strains collected in America, Africa, Asia, and Europe

\begin{tabular}{|c|c|c|c|c|c|c|c|c|c|c|c|c|c|c|c|c|c|c|}
\hline \multirow[b]{2}{*}{ Isolate } & \multirow[b]{2}{*}{ Type } & \multirow[b]{2}{*}{ Origin } & \multirow[b]{2}{*}{ Host } & \multicolumn{15}{|c|}{ Microsatellite markers ${ }^{1}$} \\
\hline & & & & TUB2 & W35 & $T g M-A$ & $B 18$ & $B 17$ & M33 & IV.1 & $X I .1$ & M48 & M102 & N60 & N82 & $A A$ & N61 & N83 \\
\hline TgSpEt2 & $\|$ & W.Shewa & Sheep & 289 & 242 & 207 & 158 & 336 & 169 & 274 & 356 & NA & 176 & NA & NA & NA & NA & NA \\
\hline TgSpEt3 & $\|$ & W.Shewa & Sheep & 289 & 242 & 207 & 158 & 336 & 169 & 274 & 356 & 211 & 176 & 140 & 123 & 259 & 091 & 308 \\
\hline TgSpEt4 & $\|$ & W.Shewa & Sheep & 289 & 242 & 207 & 158 & 336 & 169 & 274 & 356 & 211 & 176 & 140 & 123 & 259 & 091 & 308 \\
\hline TgGtEt1 & $\|$ & W.Shewa & Goat & 289 & 242 & 207 & 158 & 336 & 169 & 274 & 356 & 225 & 172 & 142 & 117 & 259 & 093 & 308 \\
\hline TgGtEt2 & $\|$ & W.Shewa & Goat & 289 & 242 & 207 & 158 & 336 & 169 & 274 & 356 & 235 & 176 & 138 & 115 & 279 & 099 & 312 \\
\hline TgGtEt3 & $\|$ & W.Shewa & Goat & 289 & 242 & 207 & 158 & 336 & 169 & 274 & 356 & 235 & 176 & 138 & 115 & 279 & 099 & 312 \\
\hline TgGtEt5 & III & E.Shewa & Goat & 289 & 242 & 205 & 160 & 336 & 165 & 278 & 356 & 213 & 190 & 147 & 113 & 267 & 089 & 312 \\
\hline TgGtEt4 & $\|$ & W.Shewa & Goat & 289 & 242 & 207 & 158 & 336 & 169 & 274 & 356 & 237 & 176 & 140 & 113 & 273 & 093 & 312 \\
\hline TgSpEt6 & ॥ & W.Shewa & Sheep & 289 & 242 & 207 & 158 & 336 & 169 & 274 & 356 & 213 & 176 & 140 & 115 & 265 & 117 & 308 \\
\hline TgGtEt8 & ॥ & E.Shewa & Goat & 289 & 242 & 207 & 158 & 336 & 169 & 274 & 356 & 211 & 178 & 142 & 109 & 285 & 085 & 310 \\
\hline TgGtEt $21^{2}$ & $\|$ & E.Shewa & Goat & NA & 242 & NA & 158 & 336 & NA & NA & 356 & NA & NA & NA & NA & NA & NA & 312 \\
\hline $\operatorname{TgGtEt} 22^{2}$ & $\|$ & E.Shewa & Goat & NA & 242 & NA & 158 & NA & NA & 274 & NA & NA & NA & NA & NA & 279 & NA & 312 \\
\hline TgGtEt12 & ॥ & E.Shewa & Goat & 289 & 242 & 207 & 158 & 336 & 169 & 274 & 356 & 213 & 176 & 140 & 115 & 261 & 089 & 308 \\
\hline TgSpEt10 & $\|$ & E.Shewa & Sheep & 289 & NA & 207 & 158 & 336 & 169 & 274 & NA & NA & NA & NA & NA & NA & NA & 312 \\
\hline $\operatorname{TgSpE} 228^{2}$ & $\|$ & E.Shewa & Sheep & 289 & 242 & 207 & 158 & 336 & 169 & 274 & 356 & 213 & 176 & 140 & 115 & 261 & 089 & 308 \\
\hline TgGtEt14 & $\|$ & E.Shewa & Goat & 289 & 242 & 207 & 158 & 336 & 169 & 274 & 356 & 233 & 174 & 140 & 113 & 269 & 097 & 312 \\
\hline TgGtEt13 & $\|$ & E.Shewa & Goat & 289 & 242 & 207 & 158 & 336 & 169 & 274 & NA & NA & NA & 140 & 113 & NA & NA & NA \\
\hline TgSpEt19 & Atypical & E.Shewa & Sheep & 289 & 240 & 201 & 156 & 340 & 163 & 272 & 360 & 209 & 218 & 147 & 127 & 283 & 099 & 342 \\
\hline TgGtEt17 & III & E.Shewa & Goat & 289 & 242 & 205 & 160 & 336 & 165 & 278 & 356 & 213 & 190 & 147 & 113 & 267 & 089 & 312 \\
\hline TgSpEt18 & $\|$ & E.Shewa & Sheep & 289 & 242 & 207 & 158 & 336 & 169 & 274 & 356 & 211 & 176 & 140 & 109 & 267 & 091 & 308 \\
\hline TgGtEt16 & ॥ & E.Shewa & Goat & 289 & 242 & 207 & 158 & 336 & 169 & 274 & 356 & 211 & 176 & 140 & 109 & 267 & 091 & 308 \\
\hline TgSpEt22 & ॥ & E.Shewa & Sheep & 289 & 242 & 207 & 158 & 336 & 169 & 274 & 356 & 219 & 176 & 140 & 111 & 267 & 097 & 310 \\
\hline TgSpEt20 & $\|$ & E.Shewa & Sheep & 289 & 242 & 207 & 158 & 336 & 169 & 274 & 356 & 213 & 178 & 140 & 115 & 261 & 091 & 308 \\
\hline TgSpEt21 & ॥ & E.Shewa & Sheep & 289 & 242 & 207 & 158 & 336 & 169 & 274 & 356 & 211 & 176 & 140 & 109 & 267 & 091 & 308 \\
\hline TgGtEt19 & $\|$ & E.Shewa & Goat & 289 & 242 & 207 & 158 & 336 & 169 & 274 & 356 & 215 & 176 & 138 & 117 & 267 & 099 & 312 \\
\hline TgSpEt23 & III & E.Shewa & Sheep & 289 & 242 & 205 & 160 & 336 & 165 & 278 & 356 & 213 & 190 & 147 & 111 & 271 & 089 & 312 \\
\hline TgSpEt25 & $\|$ & E.Shewa & Sheep & 289 & 242 & 207 & 158 & 336 & 169 & 274 & 356 & 211 & 176 & 140 & 121 & 267 & 091 & 308 \\
\hline TgSpEt26 & ॥ & E.Shewa & Sheep & 289 & 242 & 207 & 158 & 336 & 169 & 274 & 356 & 239 & 176 & 138 & 115 & 281 & 097 & 310 \\
\hline TgSpEt27 & $\|$ & E.Shewa & Sheep & 289 & 242 & 207 & 158 & 336 & 169 & 274 & 356 & 213 & 176 & 140 & 123 & 259 & 091 & 308 \\
\hline TgGtEt20 & $\|$ & E.Shewa & Goa & 289 & 242 & 207 & 158 & 336 & 169 & 274 & 356 & 213 & 176 & 140 & 115 & 261 & 089 & 308 \\
\hline TgSpEt7 & $\|$ & W.Shewa & Sheep & 289 & 242 & 207 & 158 & 336 & 169 & 274 & 356 & 225 & 172 & 142 & 117 & 261 & 093 & 308 \\
\hline TgSpEt8 & ॥ & W.Shewa & Sheep & 289 & 242 & 207 & 158 & 336 & 169 & 274 & 356 & 213 & 178 & 140 & 115 & 265 & 089 & 308 \\
\hline TgSpEt9 & ॥ & W.Shewa & Sheep & 289 & 242 & 207 & 158 & 336 & 169 & 274 & 356 & NA & NA & 140 & 115 & NA & NA & 316 \\
\hline $\begin{array}{l}\text { GAB5-GAL- } \\
\text { DOM01 }\end{array}$ & Africa 1 & Gabon & Chicken & 291 & 248 & 205 & 160 & 342 & 165 & 274 & 354 & 231 & 166 & 149 & 111 & 277 & 087 & 306 \\
\hline $\mathrm{CCH} 002-\mathrm{NIA}$ & Africa 2 & Senegal & Human & 289 & 248 & 205 & 160 & 336 & 165 & 274 & 354 & 225 & 166 & 145 & 111 & 273 & 089 & 308 \\
\hline $\begin{array}{l}\text { GAB2-GAL- } \\
\text { DOM02 }\end{array}$ & Africa 3 & Gabon & Human & 291 & 242 & 207 & 160 & 342 & 165 & 278 & 354 & 223 & 166 & 142 & 111 & 277 & 097 & 310 \\
\hline ENT & I & France & Human & 291 & 248 & 209 & 160 & 342 & 169 & 274 & 358 & 209 & 166 & 145 & 119 & 267 & 087 & 306 \\
\hline ME49 & $\|$ & USA & Sheep & 289 & 242 & 207 & 158 & 336 & 169 & 274 & 356 & 215 & 174 & 142 & 111 & 265 & 091 & 310 \\
\hline NED & III & France & Human & 289 & 242 & 205 & 160 & 336 & 165 & 278 & 356 & 209 & 190 & 147 & 111 & 267 & 091 & 312 \\
\hline VAND & Atypical & French Guiana & Human & 291 & 242 & 203 & 162 & 344 & 167 & 276 & 356 & 217 & 170 & 142 & 113 & 277 & 091 & 308 \\
\hline
\end{tabular}


Table 1 Genotyping results of T. gondii DNA with 15 microsatellite markers from 33 isolates collected in sheep and goats of Central Ethiopia and from 14 reference strains collected in America, Africa, Asia, and Europe (Continued)

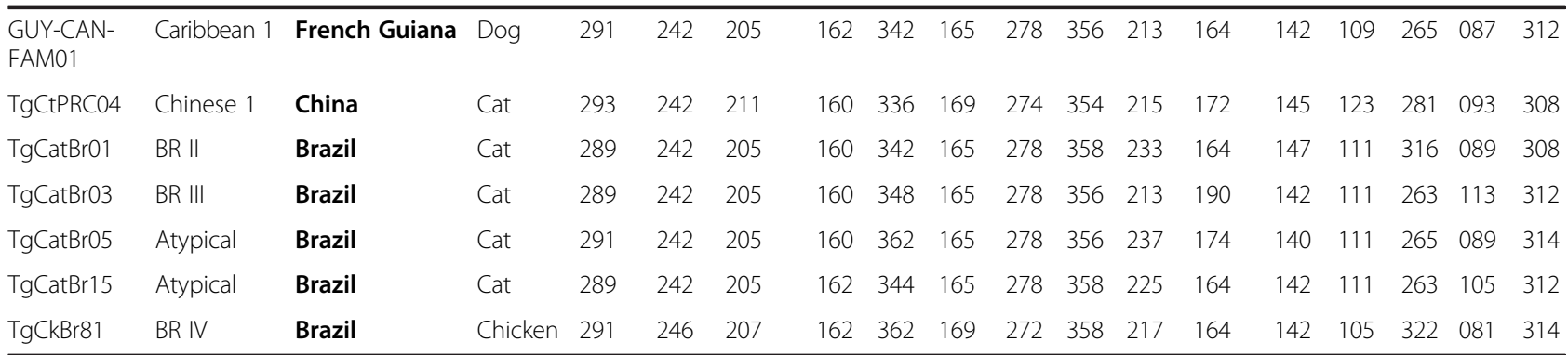

W. Shewa $=$ West Shewa Zone, E. Shewa = East Shewa Zone.

${ }^{1} \mathrm{NA}$, not amplified, ${ }^{2}$ cyst negative but nPCR positive.

companion and agricultural animals in Ethiopia [37] by mankind and consequent modification of natural biotopes that usually results in a loss of diversity $[38,39]$. This in turn decreases the probability of genetic recombination and emergence of new genotype in cats through simultaneously feeding on preys harbouring different genotypes. On the other hand, the presence of a highly divergent atypical genotype in East Shewa suggests the existence of an African gene pool with endemic T. gondii alleles in Ethiopia different from Type II. Our results in Central Ethiopia and other study in Ethiopia [15] showed that Type II strains dominate the genetic diversity in domestic animals from this part of Africa. Atypical genotypes with a different gene pool appear to be rare in anthropized environments of Ethiopia but may be more abundant in the wild where Type II strains didn't have the opportunity to penetrate yet.

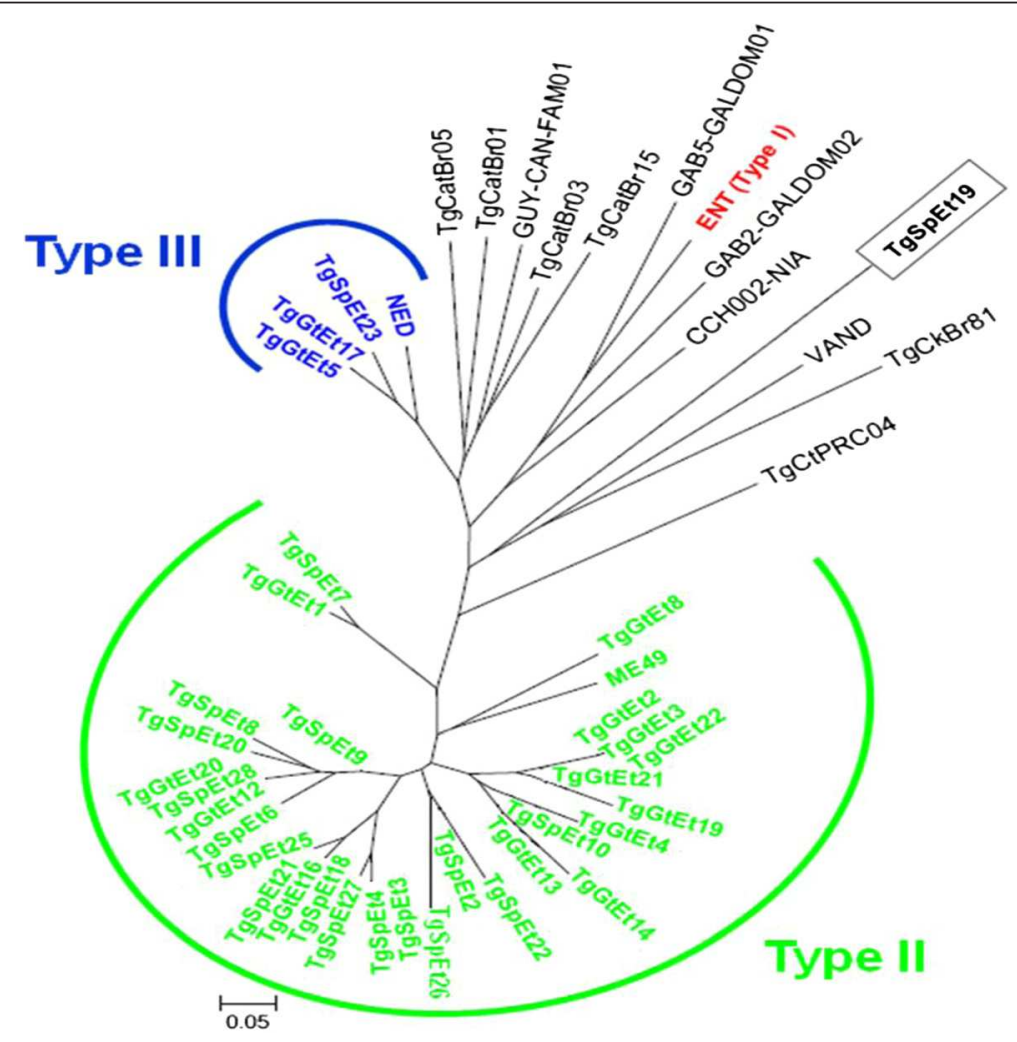

Figure 1 Neighbor-joining analysis of 33 Toxoplasma gondii strains isolated from sheep and goats (TgSp and TgGt) from Ethiopia and 14 reference strains with 15 microsatellite markers. Color-coding indicates the three major clonal types: type I (red), type II (green), and type III (blue). The atypical isolate from Ethiopia, TgSpEt19, is highlighted by a black box. 
The Type II and III genetic lineages (which constitute about $97 \%$ of the isolates of the present study) were previously also reported from feral cats of Addis Ababa. This shows that these are the most common and widespread genetic lineages of $T$. gondii in Central Ethiopia. The atypical genotype from the strain TgSpEt19 isolated in a sheep from Adea district (East Shewa Zone) comprises alleles for the markers N61, B18, N83, XI-I, N82, TgM-A, IV-I, B17, N60 and $A A$ that are markedly different from allelic composition of Type II and III strains isolated in this study (Table 1). It might perhaps be unique among isolates from other countries ever genotyped using the multiplex-PCR microsatellite method (Ajzenberg, D., personal communication). Thus, further large-scale investigation on different hosts and geographical areas in Ethiopia might reveal more atypical genotypes significantly divergent from the conventional Type I, II and III lineages. Identification of one atypical strain virulent in mice from Arsi-Bale sheep breed of Adea district is of considerable clinical and epidemiological importance as atypical strains are considered to be more pathogenic to humans than type II or III strains. For example, in immunocompetent patients, severe toxoplasmosis with multi-organ failure has been linked to atypical strains acquired from the Amazonian rainforest [40]. Similarly, severe cases of congenital toxoplasmosis in France $[7,41]$ and Suriname [42] and abortion in sheep in Uruguay $[5,43]$ were observed in relation to infection with atypical genotypes. Severe or lethal infections in immunocompetent subjects, with pneumonitis, myocarditis, meningoencephalitis, or polymyositis were also reported due to atypical genotypes [7]. Outdoor access of domestic cats, abundance of feral cats and wild felids coupled with widely practiced extensive management of animals in Ethiopia might favour high rate of transmission of toxoplasmosis with occasional possibility of cats being infected with two different genotypes followed by sexual recombination and emergence of atypical genotypes [15,33]. Supporting this reasoning, Dubey et al. [15] attributed the isolation of different genotypes from tissues and feces of two feral cats (out of 27 isolates) of Addis Ababa to re-infection or mixed strain infection.

\section{Conclusions}

The present findings indicate a high rate of isolation of T. gondii from seropositve Ethiopian small ruminants slaughtered for human consumption. The present study also revealed three genetic lineages (Type II, III and atypical) of T. gondii. This is the first report of isolation and molecular characterization of $T$. gondii infection in mice experimentally infected with heart homogenates of seropositive sheep and goats in Ethiopia.

\section{Additional files}

\section{Additional file 1: Microsatellite markers and PCR primers used for} the multiplex PCR assay.

Additional file 2: Table S1. Isolation of T. gondii from seropositive sheep of East and West Shewa Zones, Central Ethiopia. Table S2.

Isolation of T. gondii from seropositive goats of East and West Shewa Zones, Central Ethiopia.

\section{Competing interests}

The authors declare that they have no competing interests.

\section{Authors' contributions}

EZG conceived and designed the proposal, collected samples, isolated the strains, analyzed the data and drafted the article. MA assisted the bioassay work. DA did the genotyping with the help from MLD and EZG. TST, GT, EC, BG and PD participated in the study design, scientific advising of the overall work and edition of article. All authors read and approved the final manuscript.

\section{Acknowledgements}

The financial support of Oromia Regional State Rural Capacity Building, Addis Ababa University and VLIR-UOS project no. "ZEIN 2010 PR 372" "promotion of the PhD program in veterinary public health at the Faculty of Veterinary Medicine", Belgium are highly acknowledged. The authors also would like to extend their gratitude to Mr. Hashim Nuru, owner of HELMIX export abattoir and his employees for their collaboration during sampling.

\section{Author details}

${ }^{1}$ Faculty of Agriculture and Veterinary Sciences, Department of Veterinary Laboratory Technology, Ambo University, P. O. Box 19, Ambo, Ethiopia.

${ }^{2}$ College of Agriculture and Veterinary Medicine, Jimma University, P. O. Box 307, Jimma, Ethiopia. ${ }^{3}$ Institute of Biotechnology, College of Natural and Computational Sciences, Unit of Health Biotechnology, Addis Ababa University, P. O. Box. 1176, Addis Ababa, Ethiopia. ${ }^{4}$ Aklilu Lemma Institute of Pathobiology, Addis Ababa University, P. O. Box. 1176, Addis Ababa, Ethiopia. ${ }^{5}$ Faculty of Veterinary Medicine, Ghent University, Salisburylaan 133, Merelbeke B-9820, Belgium. 'Department of Biosystems, Faculty of Bioscience Engineering, Catholic University of Leuven, Kasteelpark Arenberg 30 bus 2456, Heverlee B-3001, Belgium. 7 Department of Biomedical Sciences, Institute of Tropical Medicine, Antwerp B2000, Belgium. ${ }^{8}$ Scientific Institute of Public Health, Communicable and Infectious Diseases, National Reference Center for Toxoplasmosis, Engelandstraat 642, Brussels B1180, Belgium. ${ }^{9}$ Centre National de Référence (CNR) Toxoplasmose / Toxoplasma Biological Resource Center (BRC), Centre Hospitalier-Universitaire Dupuytren, Limoges 87042, France. ${ }^{10}$ INSERM UMR 1094, Neuroépidémiologie Tropicale,

Laboratoire de Parasitologie-Mycologie, Faculté de Médecine, Limoges 87025, France.

Received: 3 August 2014 Accepted: 28 August 2014

Published: 4 September 2014

\section{References}

1. Dubey JP: Toxoplasmosis of Animals and Humans. 2nd edition. Boca Raton, Florida, U.S.A: CRC Press; 2010:1-338.

2. Wong SY, Remington J: Toxoplasmosis in pregnancy. Clin Infect Dis 1994, 18:853-862

3. Robert-Gangneux F, Dardé ML: Epidemiology of and diagnostic strategies for toxoplasmosis. Clin Microbiol Rev 2012, 25(2):264-296.

4. Howe DK, Sibley LD: Toxoplasma gondii comprises three clonal lineages: correlation of parasite genotype with human disease. J Infect Dis 1995 172:1561-1566.

5. Ajzenberg D, Bañuls AL, Su C, Dumètre A, Demar M, Carme B, Dardé ML: Genetic diversity, clonality and sexuality in Toxoplasma gondii. Int J Parasitol 2004, 34:1185-1196.

6. Ferreira ADM, Vitor RW, Gazzinelli RT, Melo MN: Genetic analysis of natural recombinant Brazilian Toxoplasma gondii strains by multilocus PCR-RFLP. Infect Genet Evol 2006, 6:22-31.

7. Ajzenberg D, Banuls AL, Tibayrenc M, Dardé ML: Microsatellite analysis of Toxoplasma gondii shows considerable polymorphism structured into two main clonal groups. Int J Parasitol 2002, 32:27-38. 
8. Ajzenberg D, Cogné N, Paris L, Bessieres MH, Thulliez P, Filisetti D, Pelloux $H$, Marty P, Dardé ML: Genotype of 86 Toxoplasma gondii isolates associated with human congenital toxoplasmosis, and correlation with clinical findings. J Infect Dis 2002, 186:684-689.

9. Ajzenberg D, Dumètre A, Dardé ML: Multiplex PCR for typing strains of Toxoplasma gondii. J Clin Microbiol 2005, 43:1940-1943.

10. Khan A, Su C, German M, Storch GA, Clifford DB, Sibley LD: Genotyping of Toxoplasma gondii Strains from immunocompromised patients reveals high prevalence of type I strains. J Clin Microbiol 2005, 43:5881-5887.

11. Khan A, Taylor S, Su C, Mackey AJ, Boyle J, Cole R, Glover D, Tang K, Paulsen IT, Berriman M, Boothroyd JC, Pfefferkorn ER, Dubey JP, Ajioka JW, Roos DS, Wootton JC, Sibley LD: Composite genome map and recombination parameters derived from three archetypal lineages of Toxoplasma gondii. Nucleic Acids Res 2005, 33:2980-2992.

12. Ferreira IM, Vidal JE, Costa-Silva TA, Meira CS, Hiramoto RM, Penalva De Oliveira AC, Pereira-Chioccola VL: Toxoplasma gondii: genotyping of strains from Brazilian AIDS patients with cerebral toxoplasmosis by multilocus PCR-RFLP markers. Exp Parasitol 2008, 118:221-227.

13. Su C, Zhang X, Dubey JP: Genotyping of Toxoplasma gondii by multilocus PCR-RFLP markers: a high resolution and simple method for identification of parasites. Int J Parasitol 2006, 36:841-848.

14. Dubey JP, Tiao N, Gebreyes WA, Jones JL: A review of toxoplasmosis in humans and other animals in Ethiopia. Epidemiol Infect 2012, 140:1935-1938.

15. Dubey JP, Choudhary S, Tilahun G, Tiao N, Gebreyes WA, Zou X, Su C: Genetic diversity of Toxoplasma gondii isolates from Ethiopian feral cats. Vet Parasitol 2013, 196:206-208.

16. Ajzenberg D, Collinet F, Mercier A, Vignoles P, Dardé ML: Genotyping of Toxoplasma gondii isolates with 15 microsatellite markers in a single multiplex PCR assay. J Clin Microbiol 2010, 48(12):4641-4645.

17. Gebremedhin EZ, Agonafir A, Tessema TS, Tilahun G, Medhin G, Vitale M, Di Marco V, Cox E, Vercruysse J, Dorny P: Seroepidemiological study of ovine toxoplasmosis in East and West Shewa Zones of Oromia Regional State. Cent Ethiop BMC Vet Res 2013, 9:117.

18. Gebremedhin EZ, Abdurahaman M, Hadush T, Tessema TS: Seroprevalence and risk factors of Toxoplasma gondii infection in sheep and goats slaughtered for human consumption in Debre Zeit, Central Ethiopia. BMC Res Notes 2014, in press.

19. Pena HF, Gennari SM, Dubey JP, Su C: Population structure and mouse virulence of Toxoplasma gondii in Brazil. Int J Parasitol 2008, 38:561-569.

20. Goodwin DG, Strobl J, Mitchell SM, Zajac AM, Linday DS: Evaluation of the mood stabilizing agent valproic acid as a preventative for toxoplasmosis in mice and activity against tissue cysts in mice. J Parasitol 2008, 94:555-557.

21. Fritz H, Barr B, Packham A, Melli A, Conrad PA: Methods to produce and safely work with large numbers of Toxoplasma gondii oocysts and bradyzoite cysts. J Microbiol Methods 2012, 88:47-52.

22. Su C, Dubey JP: Toxoplasma. In Molecular Detection of Foodborne Pathogens. Edited by Liu D. Boca Raton, New York: CRS Press; 2010:741-751.

23. Cavalli-Sforza LL, Edwards AW: Phylogenetic analysis: models and estimation procedures. Am J Hum Genet 1967, 19:233-257.

24. Cook AJC, Gilbert RE, Buffolano W, Zufferey J, Petersen E, Jenum PA, Foulon W, Semprini AE, Dunn DT: Sources of Toxoplasma infection in pregnant women: European multicentre case-control study. BMJ 2000, 321:142-147.

25. Dubey JP, Weigel RM, Siegel AM, Thulliez P, Kitron UD, Mitchell MA, Mannelli A, Mateus-Pinilla NE, Shen SK, Kwok OCH, Todd KS: Sources and reservoirs of Toxoplasma gondii infection on 47 swine farms in Illinois. J Parasitol 1995, 81:723-729.

26. Dubey JP, Shen SK, Kwok OCH, Thulliez P: Toxoplasmosis in rats (Rattus norvegicus): congenital transmission to first and second generation offspring and isolation of Toxoplasma gondii from seronegative rats. Parasitology 1997, 115:9-14.

27. Dubey JP, Thulliez P, Powell EC: Toxoplasma gondii in lowa sows: comparison of antibody titers to isolation of $T$. gondii by bioassays in mice and cats. J Parasitol 1995, 81:48-53.

28. Ragozo AMA, Yai LEO, Oliveira LN, Dias RA, Dubey JP, Gennari SM: Seroprevalence and isolation of Toxoplasma gondii from sheep from Sao Paulo State, Brazil. J Parasitol 2008, 94:1259-1263.

29. Ragozo AM, Yai LE, Oliveira LN, Dias RA, Goncalves HC, Azevedo SS, Dubey JP, Gennari SM: Isolation of Toxoplasma gondii from goats from Sao Paulo State, Brazil. J Parasitol 2009, 95:323-326.
30. Dumètre A, Ajzenberg D, Rozette L, Mercier A, Dardé ML: Toxoplasma gondii infection in sheep from Haute-Vienne, France: seroprevalence and isolate genotyping by microsatellite analysis. Vet Parasitol 2006, 142:376-379.

31. Dubey JP, Sundar N, Velmurugan GV, Bandini LA, Kwok OCH, Majumdar D, Su C: High prevalence and abundant atypical genotypes of Toxoplasma gondii isolated from lambs destined for human consumption in the USA. Int J Parasitol 2008, 38:1057-1063.

32. Dubey JP, Beattie CP: Toxoplasmosis of Animals and Man. Boca Raton, FL: CRC Press, Inc.; 1988:1-220.

33. Pena HFJ, Soares RM, Amaku M, Dubey JP, Gennari SM: Toxoplasma gondii infection in cats from Sao Paulo state, Brazil: seroprevalence, oocyst shedding, isolation in mice, and biologic and molecular characterization. Res Vet Sci 2006, 81:58-67.

34. Suzuki Y: Factors Determining Resistance and Susceptibility to Infection with Toxoplasma gondii. In Opportunistic Infections: Toxoplasma, Sarcocystis, and Microsporidia. Edited by Lindsay DS, Weiss LM. New York: Kluwer Academic Publishers; 2004:51-66.

35. Ajzenberg D, Yera H, Marty P, Paris L, Dalle F, Menotti J, Aubert D, Franck J, Bessières M-H, Quinio D, Pelloux H, Delhaes L, Desbois N, Hulliez P, RobertGangneux F, Kauffmann-Lacroix C, Pujol S, Rabodonirina M, Bougnoux M-E, Cuisenier B, Duhamel C, Duong TH, Filisetti D, Flori P, Gay-Andrieu F, Pratlong F, Nevez G, Totet A, Carme B, Bonnabau H, Dardé ML, Isabelle Villena I: Genotype of 88 Toxoplasma gondii isolates associated with toxoplasmosis in immunocompromised patients and correlation with clinical findings. $J$ Infect Dis 2009, 199:1155-1167.

36. Fekkar A, Ajzenberg D, Bodaghi B, Touafek F, Le Hoang P, Delmas J, Robert PY, Dardé ML, Mazier D, Paris L: Direct genotyping of Toxoplasma gondii in ocular fluid samples from 20 patients with ocular toxoplasmosis: predominance of type II in France. J Clin Microbiol 2011, 49:1513-1517.

37. Lemma H: Domestic animal biodiversity in Ethiopia and its threats and opportunities with emphasis to changing climate: an overview. Adv Life Sci Techol 2012, 6:33-39.

38. Chapin FS 3rd, Zavaleta ES, Eviner VT, Naylor RL, Vitousek PM, Reynolds HL, Hooper DU, Lavorel S, Sala OE, Hobbie SE, Mack MC, Diaz S: Consequences of changing biodiversity. Nature 2000, 405:234-242.

39. Mercier A, Ajzenberg D, Devillard S, Demar MP, de Thoisy B, Bonnabau H, Collinet F, Boukhari R, Blanchet D, Simon S, Carme B, Dardé M-L: Human impact on genetic diversity of Toxoplasma gondii: example of the anthropized environment from French Guiana. Infect Genet Evol 2011, 11:1378-1387

40. Carme B, Bissuel F, Ajzenberg D, Bouyne R, Aznar C, Demar M, Bichat S, Louvel D, Bourbigot AM, Peneau C, Neron P, Dardé ML: Severe acquired toxoplasmosis in immunocompetent adult patients in French Guiana. J Clin Microbiol 2002, 40:4037-4044.

41. Delhaes $L$, Ajzenberg D, Sicots B, Bourgeots P, Dardé ML, Dei-Cas E, Houfflin-Debarges $V$ : Severe congenital toxoplasmosis due to a Toxoplasma gondii strain with an atypical genotype: case report and review. Prenatal Diag 2010, 30:902-905.

42. Demar M, Ajzenberg D, Maubon D, Djossou F, Panchoe D, Punwasi W, Valery N, Peneau C, Daigre JL, Aznar C, Cottrelle B, Terzan L, Dardé ML, Carme B: Fatal outbreak of human toxoplasmosis along the Maroni River: epidemiological, clinical, and parasitological aspects. Clin Infect Dis 2007, 45:e88-e95.

43. Su C, Evans D, Cole RH, Kissinger JC, Ajioka JW, Sibley LD: Recent expansion of Toxoplasma through enhanced oral transmission. Science 2003, 299:414-416.

\section{doi:10.1186/1756-3305-7-425}

Cite this article as: Gebremedhin et al:: Isolation and genotyping of viable Toxoplasma gondii from sheep and goats in Ethiopia destined for human consumption. Parasites \& Vectors 2014 7:425. 